High summer concentrations of mercury in big perch (Perca fluviatilis $L$ ) from the Tvärminne archipelago (SW Finland) and Nåtö (Åland Islands) Baltic Sea

\author{
Voigt, H.-R. \\ WILEY-VCH Verlag GmbH \\ 2001
}

Voigt, H.-R. 2001. High summer concentrations of mercury in big perch (Perca fluviatilis L) from the Tvärminne archipelago (SW Finland) and Nåtö (Åland Islands) Baltic Sea.

pÿNahrung/Food 45 (2001) No. 2, pp. 109113

http://hdl.handle.net/1975/188

Downloaded from Helda, University of Helsinki institutional repository.

This is an electronic reprint of the original article.

This reprint may differ from the original in pagination and typographic detail.

Please cite the original version. 


\title{
High summer concentrations of mercury in big perch (Perca fluviatilis $L$ ) from the Tvärminne archipelago (SW Finland) and Nåtö (Åland Islands) Baltic Sea
}

\author{
H.-R. Voigt
}

\begin{abstract}
During high summer seasons in 1994-1999 84 big $(20-42 \mathrm{~cm}$ total length) female perch (Perca fluviatilis $\mathrm{L}$ ) were sampled from the waters around Tvärminne Zoological Station on the Hanko-Hangö peninsula on the SW coast of Finland for mercury analysis. Additional sampling of 13 big female perch during the same season were carried out from the waters of Nåtö Biological Station on the Åland Islands in 1997-1998. High summer is the most important season for perch fishing and consumption not only for private families during leisure time but also for professional fishery including trade and export, processing and preparations for restaurants.

Fillets of big specimen of perch, s.c. "fillet perch" or "sea perch" from outer coastal waters were chosen for the study to find out the levels of mercury concentration in these desirable fish. The mean con-
\end{abstract}

centration of mercury in the dorsal muscle tissue (fillet) of big female "sea perch" from the coastal waters of Tvärminne Zoological Station was calculated to 0.22 (SD 0.08), range $0.08-0.43 \mathrm{mg} / \mathrm{kg}$, f wt and for big female perch from the waters of Nåtö Biological Station to 0.18 (SD 0.07), range $0.07-0.30 \mathrm{mg} / \mathrm{kg}$, f wt respectively.

The results show a considerably lower mercury level in big "fillet perch" caught from the outer coastal waters in both Finland (and Estonia) compared with the levels recorded of big "fillet perch" from fresh water lakes and reservoirs. Thus, the common expression "sea perch" may also be used in the form "Baltic sea perch" meaning big healthy perch with low concentrations of mercury and caught from the outer coastal waters in S and SW Finland (and W Estonia) when marketing perch for human consumption.

\section{Introduction}

Fish beeing the main source of mercury intake via food in man $[1,2]$ makes the monitoring of mercury concentrations in fish important [3]. The most frequently used fish species for aquatic environmental monitoring are herring (Clupea harengus membras L), cod (Gadus morhua callarias L) in the Baltic [4-7] and pike (Esox lucius L) regarding fresh water in Finnish lakes and reservoirs [8-11]. Perch (Perca fluviatilis L) is less frequently used for monitoring although this is the most abundant and popular fish species in almost every aquatic environment in Finland [12] and Estonia [13]. Numerous studies on mercury concentrations in perch from Finnish freshwater lakes [8, 14-26] and reservoirs [18, 22, 27-31] have been conducted, but when brackish coastal waters are used there are only few rather old investigations to compare with [8, $14,32-39]$. This is rather surprising since from these waters perch is of great importance as a food supply and game fish due to its great abundance in the brackish water along the Finnish coast [12].

The potent stocks of perch have recovered from the sudden decline in the outer coastal waters along the Finnish and Estonian coast in the late 1980's [40,41]. Today there even is a considerable amount of perch to export to Central Europe, mainly Germany from these waters [42-44]. According to official statistics from the Finnish game and fisheries Research Institute [45] the total catch of perch in Finland in 1998 was 14721 tons of which 5251 tons were caught from the sea (Gulf of Finland, Archipelago Sea and Gulf of Bothnia).

For big specimen of these fish especially if also caught from the more saline waters in the outer archipelago off the coast the expression "sea perch" is widely used by fishermen in the S and SW Finnish archipelago area ("havsabborre" in Swedish and

\section{Correspondence to:}

H.-R. Voigt, University of Helsinki-Helsingfors, Department of Limnology and Environmental Protection, P. O. Box 62 (Infocenter), FIN00014 University of Helsinki-Helsingfors, Finland (e-mail: heinz-rudolf.voigt@helsinki.fi). "meriahven" in Finnish) as is the expression "fillet perch" by professionals in the food business meaning only large specimen suitable for fillet cutting regardless of origin. Thus "fillet of sea perch" in Finland means fillet of big perch caught from the outer coastal waters as the brackish waters in the Gulf of Finland around the Porkkala-Porkala and Hanko-Hangö peninsulas as around the Åland Islands as well all in S and SW Finland. The chance to missinterprete the common perch (Perca fluviatilis L) of the Family Percidae for the considerably bigger and imported sea bass Dicentrarchus labrax L from the NE Atlantic [46] is very small although for this and other non-Baltic species of the Family Serranidae the commercial names "sea bass" and "sea perch" are used in both Finnish and Swedish.

Big specimens of perch are often of female sex, females growing faster and living longer than males [12, 47] being the reason for including only females in the study. Assuming a more similar growth for each sex also supported by the aging of the material this also simplifies the division of the fish into size groups.

The aim of the study was to find out the level of mercury concentrations in these desirable big "sea perch" especially from the critical fish consumers point of view.

\section{Material and methods}

In 1994-1999 during the high summer season (July-August) in total 84 large female perch all exceeding $20 \mathrm{~cm}$ (mean $26.4 \mathrm{~cm}$ total length and range $20-42 \mathrm{~cm}$ ) of age groups 5-12 were sampled from the outer archipelago of Tvärminne Zoological Station for mercury analysis in the dorsal abdominal muscle tissue (fillet). Additional analyses were made from 13 big perch females of similar size sampled in July 1997-1998 from the outer waters of Nåtö Biological Station on the Åland Islands.

The study areas, Tvärminne archipelago $(\mathrm{T})$ and Nåtö $(\mathrm{N})$ are presented in Fig. 1. The sampling season correlates with the high seasons for perch dishes in e.g. restaurants all over the country when most perch are also caught during leisure time for private domestic consumption. 


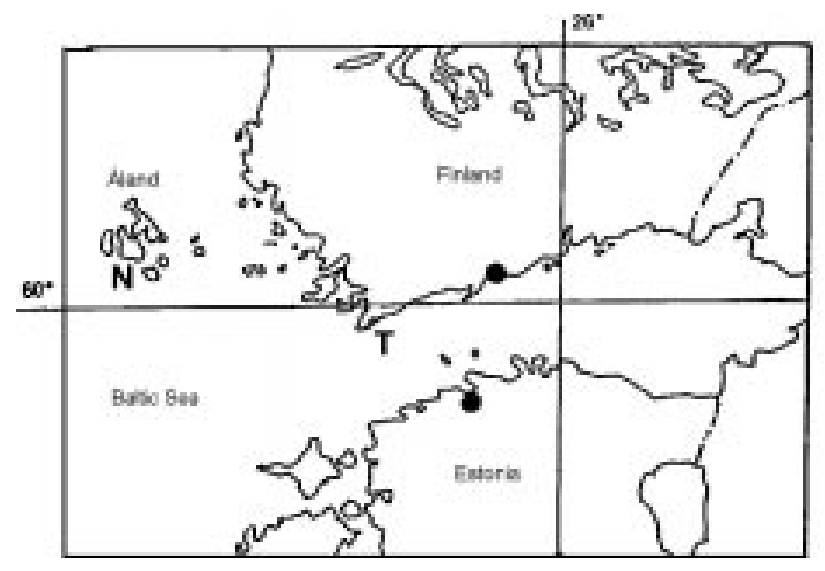

Figure 1. The locations of the two study areas; Tvärminne archipelago (T), SW Finland, and Nåtö (N), Ålands Islands.

Mercury $(\mathrm{Hg})$ was analyzed according to the cold-vapour atomic spectrophotometric method (CVAAS) as described by Hatch and Ott [48], AOAC [49] modified for analysis of fish by Uthe et al. [50], Kivalo et al. [51] and Ott et al. [52] using the Coleman Model Mercury Analyzer System (MAS-50B). All samples were analyzed in duplicate and the accuracy was assessed by using blanks and reference materials; CRM-422 cod muscle [3]. The results of the analyses are expressed in $\mathrm{mg} / \mathrm{kg}$ fresh weight $(\mathrm{mg} / \mathrm{kg}$, $\mathrm{f} \mathrm{wt})$.

\section{Results}

The results regarding concentrations of mercury in muscle tissue of big female perch from the Tvärminne archipelago are presented in Table 1 . The mean concentration of mercury was calculated for the whole material consisting of 84 female perch to $0.22 \mathrm{mg} / \mathrm{kg}$, f wt (SD 0.08) with range $0.08-0.43 \mathrm{mg} / \mathrm{kg}$, f wt. Corresponding data for the 13 female perches from Nåtö are 0.18 (SD 0.07) and range $0.07-0.30 \mathrm{mg} / \mathrm{kg}$, f wt.

Divided into size groups the concentrations of mercury increased with length (Table 2) indicating the accumulation of mercury by age. The difference of mercury concentrations between the size groups is not obvious. Instead a "typical level" of approximation $0.15-0.30$ for big perch from the waters around Tvärminne may be considered.

The correlation between weight of big female perch from the Tvärminne archipelago and mercury concentration in the

Table 1. Mean concentrations of mercury $[\mathrm{mg} / \mathrm{kg}$, $\mathrm{f} \mathrm{wt}]$ in dorsal muscle tissue of big specimen $(20-42 \mathrm{~cm}$ ) of female perch (Perca fluviatilis $\mathrm{L}$ ) from Tvärminne and Nåtö waters during high summer seasons in 1994-1999.

\begin{tabular}{lcccc}
\hline Year & Mean & SD & Range & $\mathrm{n}$ \\
\hline Trärminne & & & & \\
1994 & 0.23 & 0.08 & $0.08-0.33$ & 14 \\
1995 & 0.21 & 0.08 & $0.08-0.36$ & 12 \\
1996 & 0.23 & 0.07 & $0.11-0.33$ & 13 \\
1997 & 0.22 & 0.07 & $0.08-0.34$ & 20 \\
1998 & 0.23 & 0.10 & $0.13-0.43$ & 12 \\
1999 & 0.21 & 0.07 & $0.09-0.30$ & 13 \\
Nåtö & & & & \\
1997 & 0.18 & 0.06 & $0.07-0.26$ & 6 \\
1998 & 0.17 & 0.07 & $0.11-0.30$ & 7 \\
\hline
\end{tabular}

Table 2. Mean concentrations of mercury $[\mathrm{mg} / \mathrm{kg}$, f wt $]$ in dorsal muscle tissue of big specimen $(20-42 \mathrm{~cm}$ ) of female perch (Perca fluviatilis $\mathrm{L}$ ) from Tvärminne and Nåtö waters during high summer seasons in 1994-1999, divided into size groups; $20-24,25-29,30-34,>$ $35 \mathrm{~cm}$ of total length.

\begin{tabular}{ccccc}
\hline Size & Mean & SD & Range & $\mathrm{n}$ \\
\hline Tvärminne & & & & \\
$20-24$ & 0.18 & 0.07 & $0.08-0.31$ & 37 \\
$25-29$ & 0.26 & 0.05 & $0.13-0.33$ & 27 \\
$30-34$ & 0.27 & 0.08 & $0.11-0.36$ & 17 \\
$>35$ & 0.21 & 0.19 & $0.09-0.43$ & 3 \\
Nåtö & & & & \\
$20-24$ & 0.16 & 0.06 & $0.07-0.20$ & 8 \\
$25-29$ & 0.22 & 0.07 & $0.14-0.30$ & 4 \\
$30-34$ & 0.26 & & & 1 \\
\hline
\end{tabular}

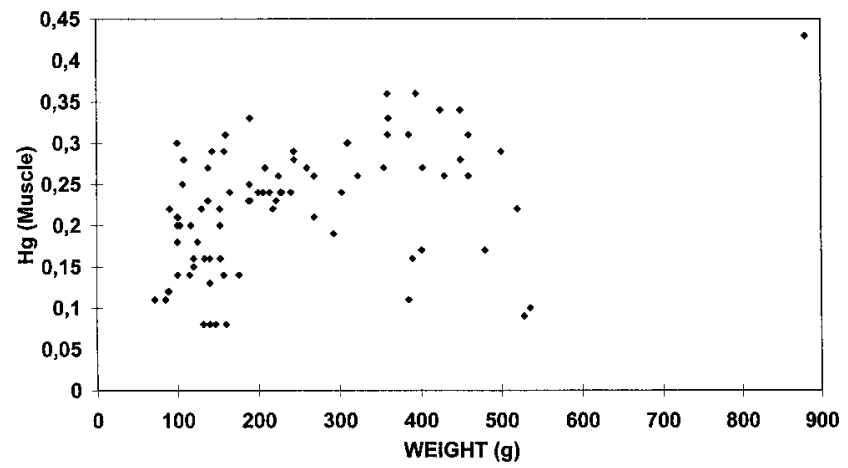

Figure 2. Concentrations of mercury $(\mathrm{mg} / \mathrm{kg}$, $\mathrm{f} w \mathrm{wt})$ in correlation to weight of big specimen $(20-42 \mathrm{~cm})$ female perch (Perca fluviatilis L) from the Tvärminne archipelago during high summer seasons in 1994-1999.

dorsal muscle tissue of these fish is presented in Fig. 2. The tendency of increasing mercury by length as shown in Table 2 is not as obvious when the concentrations of mercury are correlated with weight of the fish (Fig. 2). Instead a certain "level" of mercury concentration for such big perch may be imaginable, mean 0.22 (range 0.08-0.43).

Available data regarding mercury concentrations in perch from Finnish and adjacent Estonian coastal waters are shown in Table 3. Although perch of unknown size and of both sexes are included in the data presented in Table 3 a clear distinction for the mercury concentrations between the two categories A (outer waters) and B (inshore waters) is visible. This distinction remains even if the time aspect regarding the decline of mercury in Finnish biota as effects of the mercury ban in 1971 $[11,58]$ is taken into consideration.

Mean concentrations of mercury in perch from selected freshwater, lakes and reservoirs in Finland are presented in Table 4. The distinction of mercury concentrations between big perch from Tvärminne and the lake Saimaa (in 1968) and the reservoir Lokka (in 1980-1981) is not so clear as those between perch from Tvärminne and other lakes and especially the reservoirs from which big perch have been analysed.

The food organisms for perch in Tvärminne identified during high summer season mainly consisted of three-spined sticklebacks (Gasterosteus aculeatus L) for which a mean con- 
Table 3. Mean concentrations of mercury $[\mathrm{mg} / \mathrm{kg}, \mathrm{f} \mathrm{wt}]$ in muscle tissue of perch of both sexes from Finnish and adjacent Estonian coastal waters grouped into A. Outer coastal waters, and B. Inshore waters and river moths. (x: Calculated for present study).

\begin{tabular}{|c|c|c|c|c|}
\hline Locality & Mean & Range & $\mathrm{n}$ & Source \\
\hline \multicolumn{5}{|l|}{ Gulf of Bothnia } \\
\hline A. Kokkola-G:la Karleby & 0.22 & & 11 & [36] \\
\hline Vaasa-Vasa & 0.18 & $0.13-0.22$ & 2 & {$[35]^{\mathrm{X}}$} \\
\hline B. Tornio-Kemi-Riverm. & 0.56 & & 20 & {$[36]$} \\
\hline Ijoki-Rivermouth & 0.78 & $0.32-1.12$ & 5 & {$[35]^{\mathrm{X}}$} \\
\hline Oulu-Uleåborg & 0.56 & & 173 & {$[36]$} \\
\hline Pori-Björneborg & 0.66 & $0.32-1.22$ & 8 & {$[35]^{\mathrm{X}}$} \\
\hline Pori-Björneborg & 0.46 & & 11 & {$[36]$} \\
\hline Rauma-Raumo & 0.77 & $0.21-1.45$ & 9 & {$[35]^{\mathrm{X}}$} \\
\hline \multicolumn{5}{|l|}{ Archipelago Sea } \\
\hline A. Mariehamn & 0.17 & $0.08-0.28$ & 3 & {$[35]^{\mathrm{X}}$} \\
\hline Kumlinge & 0.23 & $0.17-0.31$ & 3 & {$[35]^{\mathrm{X}}$} \\
\hline Jurmo & 0.16 & $0.13-0.18$ & 3 & {$[35]^{\mathrm{X}}$} \\
\hline B. Piikkiö-Pikis & 0.31 & $0.13-0.44$ & 5 & {$[35]^{\mathrm{X}}$} \\
\hline "Archipelago Sea" & 0.47 & & 5 & [36] \\
\hline \multicolumn{5}{|l|}{ Gulf of Finland } \\
\hline A. Bromarf & 0.38 & $0.21-0.64$ & 3 & {$[33]^{\mathrm{X}}$} \\
\hline Porkala-Obbnäs & 0.13 & $0.06-0.22$ & 3 & {$[35]^{\mathrm{X}}$} \\
\hline Kotka (outer waters) & 0.34 & $0.22-0.56$ & 11 & {$[37]^{\mathrm{X}}$} \\
\hline Lovisa (outer waters) & 0.17 & $0.13-0.25$ & 3 & {$[35]^{\mathrm{X}}$} \\
\hline B. Helsinki-Helsingfors & 0.42 & $0.18-0.86$ & 11 & [32] \\
\hline Ahvenkoski-Abborfors & 0.58 & $0.35-0.91$ & 20 & {$[37]^{\mathrm{X}}$} \\
\hline \multicolumn{5}{|l|}{ Estonian Coast } \\
\hline A. Paldiski Bay & 0.15 & & & {$[53]$} \\
\hline Väike Väin & 0.30 & $0.17-0.37$ & 8 & {$[38]$} \\
\hline Pärnu Bay & 0.15 & & & {$[54]$} \\
\hline B. Matsalu Bay & 0.32 & $0.08-0.98$ & 303 & {$[55]^{\mathrm{X}}$} \\
\hline Matsalu Bay & 0.39 & $0.07-0.81$ & 11 & {$[56]^{\mathrm{X}}$} \\
\hline Riga Bay & 0.32 & $0.24-0.40$ & 5 & {$[57]$} \\
\hline
\end{tabular}

Table 4. Mean concentrations of mercury $[\mathrm{mg} / \mathrm{kg}$, f wt $]$ in muscle tissue of big "fillet perch", including both sexes, from fresh water lakes (L-) and reservoirs (R-) in Finland. (x: Calculated for present study).

\begin{tabular}{lccccc}
\hline Locality & Mean & Range & $\mathrm{n}$ & Period & Source \\
\hline L-Saimaa & 0.23 & $0.21-0.27$ & 5 & 1968 & {$[14]^{\mathrm{X}}$} \\
L-Ikkeläjärvi & 0.33 & & & & {$[16]$} \\
L-Alajärvi & 0.38 & $0.23-0.53$ & 5 & 1991 & {$[22]$} \\
L-Seinäjärvi & 0.38 & $0.26-0.50$ & 7 & 1991 & {$[22]$} \\
L-Päijänne S & 0.43 & $0.18-0.80$ & 100 & $1973-1978$ & {$[17]^{\mathrm{X}}$} \\
L-Päijänne N & 0.46 & $0.18-0.83$ & 100 & $1973-1978$ & {$[17]^{\mathrm{X}}$} \\
L-Näsijärvi & 1.89 & $0.85-3.11$ & 7 & 1968 & {$[14]^{\mathrm{X}}$} \\
R-Lokka & 0.24 & $0.02-0.48$ & 29 & $1980-1981$ & {$[28]$} \\
R-Gennarby & 0.52 & $0.36-0.69$ & 5 & $1997-1998$ & {$[31]$} \\
R-Sysilax & 0.52 & $0.49-0.55$ & 6 & $1994-1996$ & {$[31]$} \\
R-Kyrösjärvi & 0.90 & $0.74-1.26$ & 14 & 1987 & {$[22]$} \\
R-Kivilampi & 1.00 & $0.79-1.22$ & 10 & 1990 & {$[22]$} \\
R-Kalajärvi & 1.19 & $1.13-1.23$ & 4 & 1988 & {$[22]$} \\
& & & & & \\
\hline
\end{tabular}

centration of mercury analyzed from the whole fish (in toto) $0.02 \mathrm{mg} / \mathrm{kg}$, f wt was recorded [39]. The condition of the perch from Tvärminne was good indicated not only by the high condition factor $(\mathrm{CF}=1.18$, SD 0.15 , range $0.89-1.74)$ but also by the absence of visible diseases and macroscopical parasites. For similarly healthy perch from Nåtö the corresponding values were: $\mathrm{CF}=1.16$, $\mathrm{SD} 0.17$, range $0.89-1.38$.

\section{Discussion}

In comparison with corresponding data of perch of approximately similar size from other adjacent coastal regions in Finland and Estonia these results regarding concentrations of mercury in big perch do not show a decline of mercury by time for perch in Tvärminne during the high summer seasons in 19941999 (Table 1).

Instead a "level of stability" ranging $0.09-0.43 \mathrm{mg} / \mathrm{kg}$, f wt may be considered for big perch caught from the outer coastal waters in S and SW Finland (Tables 1 and 2). When compared to big "fillet perch" from fresh water lakes or reservoirs the concentrations of mercury in "sea perch" caught from the coastal waters of Tvärminne and Nåtö in most known cases were considerably lower (Table 4). The main food for big perch in Tvärminne during high summer season is fish, especially three-spined stickleback (this study). The short life time (2-3 years) and the short period spent in coastal waters during spawning season (June-July) of these otherwise open sea fish [59-61] explain the low concentrations of mercury in the sticklebacks as there is no mercury pollution in the open sea of the Baltic [62-64].

This almost mercury free food apparently maintain the good health condition of the perch indicated by only few cases of diseased or parasited perch that were observed during the study. Whether an absense of important enemies for the large "sea perch" in these waters is a significant factor regarding the health condition of perch was not considered in this study.

As the material consisted deliberately of big specimen of females caught during the high summer season the results in particular show the probable doses of mercury reaching humans by consuming these desired fish both at home and in restaurants.

The concentration of mercury exceeded the proposed security level for consumption of fish more often than once a week $(0.5$ $\mathrm{mg} / \mathrm{kg}$, f wt) in only one single case when a 10 year old big female $(40 \mathrm{~cm}$ ) was caught during spawning season in may 1998 (not included in the study) for which a concentration of $0.64 \mathrm{mg} / \mathrm{kg}, \mathrm{f}$ wt mercury was recorded in the muscle tissue. Thus Baltic "sea perch" from the Tvärminne and Nåtö waters is quite safe for human consumption regarding mercury according to the recommendations by health and other authorities [65-67]. All forms of trade with fish containing more mercury than $1 \mathrm{mg} / \mathrm{kg}$, f wt is prohibited in Finland [68] but according to the European Commission [7] perch is not included in the list of species for which this concentration is allowed, meaning a maximum limit of $0.5 \mathrm{mg} /$ kg mercury, f wt ("of the edible parts") for this species. The customer also has to be informed when and where the fish he is buying are caught [69].

This may be valuable information for e.g. fish buyers and restaurants when marketing desirable "fillet perch" for consumption by critical gourmets with awarness of their own health and the condition of the environment.

\section{Acknowledgements}

I thank my colleagues Dr. Sc. Martin Lodenius and Cand. Sc. Esa Tulisalo for inestimable help of the study.

\section{References}

[1] Linko, R. R., Ympäristö ja Terveys 7(2) (1976) 181-195 (in Finnish). 
[2] Varo, P., and P. Koivistoinen, Acta Agriculturae Scandinavica Suppl. 22 (1980) 165-171.

[3] Quevauviller, P., J. L. Imbert, P. J. Wagstaffe, G. N. Kramer and B. Griepnik, Commission of the European Communities BCR Information - Reference materials, ECSC-EEC-EAEC Report EUR 14557 EN (1993) 1-64, Brussels-Luxembourg.

[4] ICES (International Council for Exploration of the Seas), Report of the ICES advisory committee on marine pollution, 1978. ICES Cooperative Research Report 84 (1979) 1-26, Charlottenlund.

[5] HELCOM (Helsinki Commission), Guidelines for the Baltic monitoring programme for the second stage. Baltic Marine Environment Protection Commission-Helsinki Commission (1983) 1-249.

[6] HELCOM (Helsinki Commission). Third periodic assessment of the state of the marine environment of the Baltic Sea, 1989-93. Baltic Environment Proceedings 64B, Helsinki Commission (1996) 1-252.

[7] European Commission. Europe's Environment. European Environment Agency (1995) 1-676, Copenhagen.

[8] Häsänen, E., and V. Sjöblom, Suomen Kalatalous-Finlands Fiskerier 36 (1968) 5-24 (English summary).

[9] Leskinen, J., O. Lindqvist, J. Lehto and P. Koivistoinen, Publications of the Water Research Institute. National Boards of Waters, Finland 65 (1986) 72-79.

[10] Verta, M., S. Rekolainen, J. Mannio and K. Surma-Aho, Publications of the Water Research Institute. National Board of Waters, Finland 65 (1985) 21-31.

[11] Lodenius, M., Water, Air and Soil Pollution 56 (1991) 323-332.

[12] Koli, L., Suomen Kalat. WSOY, Porvoo 1990, 1-375 (in Finnish).

[13] Mikelsaar, N., Eesti NSV Kalad. Valgus, Tallinn 1984, 1-432 (in Estonian).

[14] Sjöblom, V., Nordisk Hygienisk Tidskrift 2 (1969) 37-53 (in Swedish).

[15] Hattula, M.-L., J. Särkkä, J. Janatuinen, J. Paasivita and A. Roos, Environm. Pollution 17 (19) (1978) 19-29 (in Finnish).

[16] Sukharoen, S., Ympäristö ja Terveys 11(1) (1980) 23-27 (in Finnish).

[17] Paasivirta, J., and R. Linko, Chemosphere 9 (1980) 643-661.

[18] Surma-Aho, K., J. Paasivirta, S. Rekolainen and M. Verta, Chemosphere 15 (3) (1986) 353-372.

[19] Metsälä, T., and M. Rask, Aqua Fennica 19 (1) (1989) 41-46.

[20] Verta, M., J. Mannio, P. Iivonen, J.-P. Hirvi, O. Järvinen and S. Peipponen, in: Acidification in Finland: Finnish Acidification Programme HAPRO 1985-1990. Ed. by P. Kauppi, pp. 883908. Springer Verlag, Berlin-Heidelberg 1990.

[21] Rask, M., and T.-R. Metsälä, Water, Air and Soil Pollution 56 (1991) 369-378.

[22] Kallioniemi, $H$., Vesi-ja Ympäristöhallituksen Monistesarja 484 (1993) 1-80 (in Finnish).

[23] Klein, P., Kala-ja Riistahallinnon Julkaisuja 11 (1994) 1-86 (in Finnish).

[24] Witick, A., and H. Salo, Ympäristö ja Terveys 25 (7-8) (1994) 15-19 (in Finnish).

[25] Berninger, K., and J. Pennanen, Water Air and Soil Pollution 81 (1995) 283-294.

[26] Rask, M., and M. Verta, Water Air and Soil Pollution 80 (1995) 577-580.

[27] Verta, M., National Board of Waters, Finland. Report 212 (1981) 47-69 (in Finnish)

[28] Lodenius, M., A. Seppänen and M. Herranen, Water Air and Soil Pollution 19 (1983) 237-246.

[29] Porvari, P., The Science of Total Environm. 213 (1998) 279290.

[30] Porvari, P., and M. Verta, Suomen Ympäristö 175 (1998) 5-37 (English summary).

[31] Voigt, H.-R., Concentrations of heavy metals in fish from Finnish coastal waters and two coastal freshwater reservoirs (Gennarby and Sysilax). Poster, Kemia-Kemi-Chemistry -98, Helsinki-Helsingfors Fair Center 3.-5. 11. 1998.

[32] Lehtonen, H., Ympäristö ja Terveys 4 (9-10) (1973) 847-851 (in Finnish).
[33] Nuorteva, P., and E. Häsänen, Ann. Zool. Fennici 12 (1975) $247-254$.

[34] Lind, E. A., and K. Hanski, Ympäristö ja Terveys 6(7) (1976) 479-484 (in Finnish).

[35] Lakomaa, E.-L. and E. Häsänen, Kuluttaja-asiain osasto. Julkaisuja A 1 (1978) 1-12 (in Finnish).

[36] Miettinen, V., and M. Verta, Finnish Marine Research 244 (1978) 219-226.

[37] Kokko, H., and L. Lindell, Vesi-ja ympäristöhallituksen Monistersarja 81:1-50 (in Finnish).

[38] Voigt, H.-R., Proc. Estonian Acad. Sci. Ecol. 4(3) (1994) 128 135.

[39] Voigt, H.-R., Concentrations of heavy metals in fish from the Tvärminne waters. Poster, Tvärminne Zoological Station, University of Helsinki-Helsingfors, 1998.

[40] Voigt, H.-R., Memoranda Societatis pro Fauna et Flora Fennica 67 (1991) 107-113.

[41] Voigt, H.-R., Skärgård 17 (3) (1994) 38-44 (in Swedish).

[42] Voigt, H.-R., Fiskeritidskrift för Finland 37(5-6) (1993) 10-13 (in Swedish).

[43] Voigt, H.-R., Fiskeritidskrift för Finland 38(5-6) (1994) 12-14 (in Swedish).

[44] Vetemaa, M., A. Järvält and V. Vaino, BAFICO Seminar on Inland Fisheries. TemaNord 600 (1999) 19-28, Copenhagen.

[45] Finnish Game and Fisheries Research Institute, The whole catch 2/2000. http//www.rktl.fi/english/statistics.

[46] Whitehead, P. J. P., M.-L. Bauchot, J.-C. Hureau, J. Nielsen and E. Tortonese (Eds.), Fishes of the North-eastern Atlantic and the Mediterranean 1-3. Unesco, Paris 1986, 1-1473.

[47] Curry-Lindahl, K., Våra Fiskar. P. A. Norstedts \& Söners Förlag, Stockholm 1985, 1-528 (in Swedish).

[48] Hatch, W. R., and W. L. Ott, Analytical Chemistry 40 (14) (1968) $2085-2087$.

[49] AOAC (Association of Official Analytical Chemists), Official methods of analysis 11th edition (1970) 1-1015, Washington, DC.

[50] Uthe, J. F., F. A. J. Armstrong and M. P. Stainton, J. Fisheries Research Board Canada 27 (4) (1970) 805-811.

[51] Kivalo, P., A. Visapää and R. Bäckman, Analytical Chemistry 46(12) (1974) 1814-1817.

[52] Ott, R., E. Lipre, K. Ilmoja and H. Uus, Sov. med. sanitarnogigien, issled. Primennie i praktike sanitarn, kontrolja (1978) 113, Tartu (in Russian).

[53] Ott, R., and H. Jankovski, Finnish Marine Research 247 (1980) 68-72.

[54] Poder, T. A., Rabota vip. inst. termofisik. elektrofisik. Akad. Nauk. Estonskoj SSR, Tartu 1981, 1-15 (in Russian).

[55] Ott, R., Maatsalu Riiklik Looduskaitseala Loodusevaatlusi 94 (1995) 79-89 (in Estonian).

[56] Kakum, T., Matsalu Looduskaitseala Loodusevaatlusi 95/96 (1997) 58-64 (in Estonian).

[57] Ott, R., H. Jankovski, O. Kikas, E. Lipre, A. Paju, T. Poder and K. Zagel, in: Eesti Rannikumere Kaitse. Ed. by A. Järvekülg, pp. 93-100. Valgus, Tallinn (in Estonian).

[58] Nuorteva, P., M. Lodenius and S.-L. Nuorteva, Aquilo Ser. Zool. 19 (1979) 97-100.

[59] Lemmetyinen, R., and J. Mankki, Merentutkimuslaitoksen Julkaisuja-Havsforskningsinsitutets Skrifter 239 (1975) 155-161.

[60] Leinikki, J., Aqua Fennica 25 (1995) 71-75.

[61] Candolin, U., and H.-R. Voigt, Animal Behaviour 56 (1998) 1205-1211.

[62] Olausson, E., O. Gustafsson, T. Mellin and R. Svensson, Meddelanden från Maringeologiska laboratoriet 9 (1977) 1-28, Göteborg.

[63] Brügmann, L., Rapp. P.-v. Re'un. Cons. int. Explor. Mer. 186(4) (1986) 329-342.

[64] HELCOM (Helsinki Commission), First assessment of the state of the coastal waters of the Baltic Sea. Baltic Sea Environment Proceedings 54, Helsinki Commission (1993) 1-155.

[65] National Board of Health, Finland (Lääkintöhallitus-Medicinalstyrelsen), Ohje-Direktiv No 7656/563/1 (Finnish-Swedish) 8. 7. 1971. 
[66] National Board of Health, Finland (Lääkintöhallitus-Medicinalstyrelsen) 1981. Kirje-Brev No 0574/563/80 (Finnish-Swedish) 16. 12. 1981.

[67] European Commission, Commission decision of 19 may 1993 No 93/352/EEC. Official Journal of the European Communities L 144 (1993) 23-24.
[68] Ministry of Trade and Industry, Decree B 271 (Finnish-Swedish) 9. 11. 1984.

[69] Ministry of Trade and Industry, Decree 108 (Finnish-Swedish) 25. 1. 1993.

Received: 05 May 2000.

Accepted: 09 August 2000. 